\title{
Understanding Exchange Rates: A Weakening U.S. Dollar--Good, Bad, or Indifferent for Florida Farmers and Agribusinesses? 1
}

Edward A. Evans ${ }^{2}$

\section{Introduction}

Since 2002, the U.S. dollar has fallen or weakened by as much as 35 percent against the European euro and 24 percent against the Japanese yen (Chipello 2004; Sanger, 2005). The weakening U.S. dollar is very much talked about, but should farmers in general and those in Florida in particular really care? Is the falling U.S. dollar good, bad, or indifferent for the growers and agribusinesses in the South?

This publication explains the concept of fluctuating currency exchange rates, defines common terms used (such as strengthening or weakening of the dollar), discusses factors that determine the exchange rate, considers the potential implications of a weak U.S. dollar on U.S. and South Florida agriculture in general, and makes a few suggestions regarding what farmers and agribusinesses can do to protect themselves from currency fluctuations.

\section{What Is the Exchange Rate and Why Is It Important?}

The exchange rate is simply the price of one country's currency expressed in another country's currency. In other words, the rate at which one currency can be exchanged for another. For example, the exchange rate between the U.S. dollar and the Japanese yen is US\$1 = 104 yen, the rate at which you could exchange (sell) your dollars for Japanese yen is 1:104 (i.e., for each dollar you exchange, you receive 104 yen). Likewise the exchange rate between the dollar and the euro is US $\$ 1=0.75$ euro (i.e., for each dollar you exchange, you receive 0.75 euro). It should be noted that these exchange rates change on a daily basis; therefore, the rates used here are only for illustrative purposes. The actual rates can be found online at the Federal Reserve Board's website (http://www.federalreserve.gov/releases/G5/current/ default.htm).

\footnotetext{
1. This is EDIS document FE546, a publication of the Department of Food and Resource Economics, Florida Cooperative Extension Service, Institute of Food and Agricultural Sciences, University of Florida, Gainesville, FL. Published April 2005. Please visit the EDIS website at http://edis.ifas.ufl.edu.

This publication is part of the Understanding Trade Policy Issues series. Others in the series include FE492 (Understanding the WTO Sanitary and Phytosanitary Agreement) and FE498 (Understanding Trade Adjustment Assistance for Farmers Program).

2. Edward A. Evans, Assistant Professor, Department of Food and Resource Economics, Tropical Research and Education Center, Homestead, FL, Florida Cooperative Extension Service, Institute of Food and Agricultural Sciences, University of Florida, Gainesville, FL.
}

The Institute of Food and Agricultural Sciences (IFAS) is an Equal Opportunity Institution authorized to provide research, educational information and other services only to individuals and institutions that function with non-discrimination with respect to race, creed, color, religion, age, disability, sex, sexual orientation, marital status, national origin, political opinions or affiliations. U.S. Department of Agriculture, Cooperative Extension Service, University of Florida, IFAS, Florida A. \& M. University Cooperative Extension Program, and Boards of County Commissioners Cooperating. Millie Ferrer, Interim Dean 
The exchange rate is important because it allows for the conversion of one country's currency into that of another, thereby facilitating international trade for purchases of goods and services and/or transfer of funds between countries, and it allows price comparison of similar goods in different countries. In general, the price difference between similar goods determines which goods are traded and where they are shipped or sourced. Hence, the exchange rate is a significant factor influencing the competitiveness of agricultural commodities and the profitability of farming enterprises.

\section{Who or What Determines the Level of the Exchange Rate?}

A wide range of factors interact to determine the exchange rate level: the government, market forces of supply and demand for a particular country's currency, interest rates, inflation, a country's balance of trade and/or payments, and consumers' expectations about what will happen in the future.

While a discussion of the relationships among these factors is beyond the scope of this publication (in fact some of these relationships are still unknown), the discussion can be simplified by focusing on the two main factors influencing the level of the exchange rate: the government and market forces of supply and demand.

\section{How Does the Government and Market Forces Influence the Rate (Level) of the Exchange Rate?}

Governments can influence the level of the exchange rate directly or indirectly. Governments influence the exchange rate level directly by setting "fixed" exchange rates. This means that the rates stay at the same value until such time as a government sees fit to change them. For example, since 1994, China has fixed (pegged) its exchange rate relative to the U.S. dollar at 8.28 yuan $=$ US $\$ 1$. Governments influence the exchange rate level indirectly by changing interest rates (the amount of money in circulation) or by purchasing other currencies on foreign exchange markets (the place where different currencies are bought and sold).
In addition, many countries, including the United States, Japan, and Canada, set "flexible" or "floating" exchange rates that change on a daily, or even hourly, basis, depending on currency demand and supply. Figure 1 illustrates how the U.S. dollar exchange rate for the European euro changed over the period 2001 to 2004. The downward sloping curve indicates a weakening of the U.S. dollar.

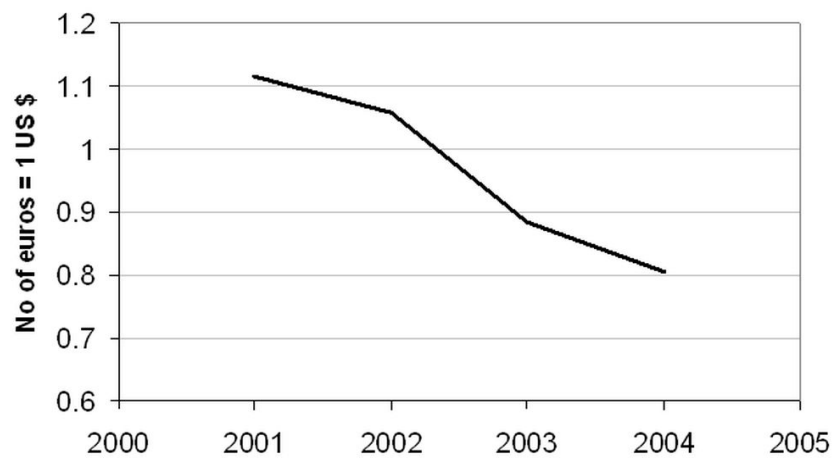

Figure 1. U.S. exchange rate of U.S. dollar versus euro, 2001-2004. Credits: Source: Compiled by author with data from Federal Reserve Board

In general, when the exchange rate increases (i.e., a unit of your currency is worth more in foreign currency than previously), the currency is said to have strengthened, appreciated, or increased in value (revaluation). For example, assume that the exchange rate between the U.S. dollar and the Japanese yen changed from US $\$ 1=104$ yen to US $\$ 1=110$ yen. This would strengthen the value of the U.S. dollar in that you would receive more yen in exchange for your dollar. Conversely, had the exchange rate changed to US $\$ 1=100$ yen, the dollar would have weakened, depreciated, or decreased in value (devaluation) because now you would receive less yen for each dollar you exchange.

An increase in the demand for a country's currency on the foreign exchange market usually increases the value of its currency, too. For example, increased demand for U.S. exports would translate into a stronger U.S. dollar because other countries would be demanding more U.S. dollars in order to pay for these commodities and services. Likewise, foreigners wishing to invest in the United States or to repay debts owed to the United States would cause the demand for U.S. dollars to increase, which would result in the appreciation of the U.S. dollar. Of 
course, the converse is also true. Factors that increase the supply of or decrease the demand for a country's currency on the foreign exchange market tend to cause the exchange rate for that currency to weaken or lose value. Such factors include the desire of U.S. consumers and businesses to purchase foreign goods and services, or to transfer or repay debts owed outside the United States.

\section{What Are the Impacts of Changes in the Exchange Rates?}

As noted earlier, a change in the exchange rate can, in the short run, affect the demand for and supply of commodities, and the competitiveness of U.S. agriculture. When the U.S. dollar strengthens or gains in value, it causes importers to pay more for the U.S. dollar to buy U.S. commodities. While a stronger U.S. dollar increases prices for importing (foreign) countries, it decreases the demand for U.S. commodities abroad. It also decreases U.S. domestic prices and increases the number of domestic commodities. This could seriously affect the profitability of an enterprise, especially in cases where profit margins are already thin. However, when the U.S. dollar is strong, U.S. businesses and consumers can purchase foreign goods and services at cheaper exchange rates (e.g., US $\$ 1=104$ yen). This encourages foreign imports because U.S. importers can pass on some of the cost savings to U.S. consumers in the form of lower prices. By and large, U.S. consumers benefit from a strong U.S. dollar. In general, while a strong U.S. currency makes our goods less competitive abroad and at home, which could negatively influence a farm's profitability, it also makes imported goods from abroad cheaper, and our commodities (locally produced) less competitive in the domestic market. This encourages imports and discourages exports.

On the other hand, when the U.S. dollar weakens or decreases in value, foreigners pay less for the U.S. dollar, and U.S. consumers and businesses pay more for a unit of foreign currency. This has the opposite effect of a strengthened U.S. dollar. A weak U.S. dollar decreases the cost of and increases the demand for U.S. commodities and services abroad. An increased demand abroad for U.S. commodities causes U.S. domestic prices and profits to increase.
However, a weakened dollar means U.S. importers must now pay more for a unit of foreign currency, which increases prices to U.S. consumers for imported goods and services. This in turn could cause U.S. demand for foreign goods and services to decrease. In this situation, locally-produced commodities stand a better chance of competing with foreign imports. In general, while a weak U.S. currency makes our goods more competitive abroad and at home, which could positively influence a farm's profitability, it also makes goods imported from abroad more expensive, and our commodities more competitive in the domestic market since it discourages imports.

\section{Why Is the Exchange Rate Important for U.S. and Florida Agriculture?}

International trade in agriculture is extremely important for the U.S. farm economy since approximately 25 percent of the U.S. gross cash farm income comes from exports. According to the United States Department of Agriculture (USDA), agriculture is twice as dependent on overseas markets as the rest of the U.S. economy. Nearly 50 percent of the wheat crop produced in the United States is exported abroad, followed by approximately 33 percent of the soybean, tobacco, and cotton crops, and 20 percent of the corn crop. Increasingly, fruits and vegetables and animal products are becoming more dependent on overseas markets (USDA). For example, between 1991 and 2003, the value of U.S. exports of fruits and vegetables increased by 55 percent (from US\$4.4 million to US\$6.8 million).

A weakened U.S. dollar makes U.S. agricultural exports more competitive abroad, as well as at home, since it makes imports more expensive, allowing domestically-produced commodities a better chance to compete with foreign markets. This means that, while a weak U.S. dollar has a positive effect on the U.S. farming sector, a strong U.S. dollar does just the opposite (U.S. agriculture loses market shares to foreign competitors).

Although Florida is not regarded as a major agricultural exporting state when compared with states such as Iowa, Indiana, Illinois, or California, it has begun to play an important role in the gross 
revenues of producers. Currently, approximately 17 percent ( $\$ 1.2$ billion) of Florida's gross farm cash income is from exports. Overseas sales of fruits and vegetables account for the bulk of the share (62.4 percent). Like the rest of the U.S. farming sector, Florida farmers stand to benefit from a weak U.S. dollar in at least two ways:

1. A weak U.S. dollar increases the demand for exported commodities, which may increase domestic revenues.

2. A weak U.S. dollar increases the price of imported commodities, which allows locally-produced commodities a better chance to compete in the domestic market.

The answer to whether the weakening U.S. dollar is good for U.S. and Florida farmers and agribusinesses appears obvious: it is good. However, there is one caveat. While it is true that in general a weak U.S. dollar benefits local farmers and agribusinesses, a dramatic slide or continued weakness in the value of the U.S. dollar could be bad for U.S. and Florida agriculture. The most obvious way to understand this is to note that a weak U.S. dollar also increases the cost of imported inputs (such as imported energy and fertilizers) that go into the production process. An increase in the energy bill (e.g., increased foreign oil prices) could erode any gains that U.S. and Florida agriculture could receive from a weak U.S. dollar. A sharp decline in the value of the U.S. dollar could also cause the U.S. government to increase interest rates to control inflation, which would increase the cost of capital and cause harm to the farming community. So while a weak U.S. dollar is good for the farmer up to a point, beyond that it could become bad for farmers. The moral is: too much of a good thing is good for nothing.

\section{Is There Anything that Farmers Could Do to Benefit from Exchange Rate Fluctuations?}

As discussed earlier, changes in exchange rates can benefit as well as hurt farmers. All farmers, and especially those relying on foreign markets, need to understand exchange rates and to implement measures to protect themselves. While there is not much that farmers can do to influence the direction of change in exchange rates, there are a few things that farmers and agribusinesses can do to protect their interests from the vagaries of the exchange rate:

- Explore the potential of hedging commodities and currencies on the futures and option markets when opportunity exists.

- Pre-sell commodities to foreign countries and pre-buy foreign inputs if you believe the exchange rate is likely to weaken (decline in value).

- If possible, delay both pre-selling commodities abroad and purchasing foreign capital items if there is the likelihood that the exchange rate will strengthen (gain in value).

- In some cases, it may make sense to draw up contracts in U.S. dollars rather than in the currency of trading partners. This would be the case where you are purchasing inputs from a foreign supplier and believe that U.S. currency is expected to weaken or that foreign currency is expected to strengthen.

- Pre-buy foreign currencies if you believe that the exchange rate is likely to weaken.

\section{Available Online Resources}

Resources are available online at the Federal Reserves Statistical Release website (http://www.federalreserve.gov/releases/h10/update).

\section{References}

Chipello, C. 2004. Dollars Slide Leaves Global Impact. The Wall Street Journal. Wednesday, December 29.

Sanger, D. 2005. U.S. Faces More Tension Abroad as Dollar Slides. The New York Times, January 25.

USDA. 2005. Importance of Trade for Agriculture. Factsheet, FAS Online, http://www.fas.usda.gov/ustrade.asp 